\title{
O Píer Mauá como Terrain Vague: Planejamento urbano, mídia e arquitetura
}

\author{
Bianca Manzon Lupo \\ Doutoranda e Mestre em Arquitetura e Urbanismo, FAU USP. \\ Contato: bianca.lupo@usp.br
}

\section{RESUMO}

A adesão ao planejamento estratégico e a realização de mega eventos esportivos no Rio de Janeiro contribuíram para a reconstrução da imagem global da cidade no século XXI, configurando novas formas de ocupação do território. Este artigo pretende refletir sobre o conceito de terrain vague, ou terreno vago (SOLÀ-MORALES, 2002), a partir da análise do Píer Mauá, atracadouro originalmente construído em 1948, na região portuária, e que se tornou objeto de disputas urbanas desde os anos 1990 até a construção do Museu do Amanhã, inaugurado em 2015. O presente estudo levanta a hipótese de que planejamento urbano e mídia se tornam fatores essenciais para nortear o pensamento arquitetônico. Investigaremos as principais propostas realizadas para o local (projetos dos anos 1990, Guggenheim Rio e Museu do Amanhã) em conexão com os respectivos planos urbanísticos (Rio Sempre Rio, Porto do Rio e Porto Maravilha) e com as imagens dominantes veiculadas pela mídia (Brasil + 500, Novo Milênio e Sustentabilidade).

Palavras-chave: Terreno vago; Píer Mauá; Guggenheim Rio; Museu do Amanhã.

\section{The Mauá Pier as a Terrain Vague: Urban planning, media and architecture}

\begin{abstract}
Strategic urban planning and mega sporting events in Rio de Janeiro have contributed to the reconstruction of the city's global image in the $21^{\text {st }}$ century, configuring new ways of occupying the territory. This article aims to reflect about the concept of terrain vague (SOLÀ-MORALES, 2002) by analyzing the Mauá Pier, a wharf originally built in 1948 at the Rio Port area, and which had become a target of territorial disputes since the 1990 s until the construction of the Museum of Tomorrow, inaugurated in 2015. This study will raise the hypothesis that both urban planning and media become fundamental factors for the architectural design thinking for the Maua Pier. Therefore, we will investigate the main architectural designs (including the proposals of the 1990s, Guggenheim Rio and Museum of Tomorrow) connected to the respective urban plans (Rio Sempre Rio, Porto do Rio and Porto Maravilha) and to the dominant images broadcasted by media (Brazil + 500, New Millennium and Sustainability).
\end{abstract}

Keywords: Terrain vague; Píer Mauá; Guggenheim Rio; Museu do Amanhã. 


\section{Introdução. O conceito de terrain vague e o Píer Mauá}

A expressão francesa terrain vague, proposta por Ignasi de Solà-Morales (2002) em 1995, é um conceito largamente utilizado do ponto de vista teórico, referindo-se aos espaços urbanos vazios que comumente permanecem abandonados, desocupados e às margens das iniciativas de planejamento urbano oficial. O termo "terreno" diz respeito ao espaço urbano, diferentemente da noção de "terra", que se relaciona principalmente ao aspecto econômico. Por sua vez, o conceito "vago" possui distintas raízes etimológicas. Sua origem germânica woge alude semanticamente a instabilidade e oscilação. Do francês vacuus, indica vacância, vazio e disponibilidade. Do latim vagus, pode ser associado à condição de abandono, físico ou semântico, e à noção de potencialidade. A expressão terrain vague tem sido usada para enfatizar a condição de expectativa por um uso potencial de determinados espaços, apesar de muitos desses terrenos serem animados por eventos espontâneos, informais e efêmeros. Mesmo que sejam pretensamente esquecidos, esses locais podem repentinamente tornar-se alvos de disputas territoriais por diversos agentes, buscando sua incorporação aos mercados produtivos. O terreno vago não é um tipo de espaço, mas uma atitude especulativa que se alimenta das projeções sobre o que pode ser realizado futuramente num determinado local (DAVIDSON, 1994; FLORES, 2015; COLMENARES, 2019).

A disponibilidade casual de específicos lugares urbanos cria um campo de ação para as forças especulativas que tentam ocupá-los, geralmente mediante a implantação de programas arquitetônicos multifuncionais - tais como hotéis, shopping centers, projetos culturais e atrações turísticas. Os terrenos vagos podem ser criados a partir da demolição ou obsolescência de infraestruturas existentes, associando-se a processos de desindustrialização frequentes na fase pós-industrial do capitalismo, que ocorrem em paralelo à expansão da economia de serviços e entretenimento. A sensação de abandono se converte num estímulo para a reciclagem de arquiteturas presentes no lugar. Em particular, a ação especulativa se torna um fator fundamental para guiar processos de renovação do território, levando "à produção precoce de espaços esvaziados, particularmente em áreas centrais” (SANT'ANNA, 2017, p. 15). Nesse contexto, amplos setores urbanos e bairros antigos abandonados se converteram em importantes fronteiras de reprodução do capital imobiliário a partir de intervenções marcadas pela lógica do negócio, ancoradas em articulações entre poder público e privado. Por essa razão, ações voltadas ao planejamento estratégico, city marketing e cidade-empreendimento contribuem para a criação de expectativa pela ocupação dos terrenos vagos (HARVEY, 2005; ARANTES; VAINER; MARICATO, 2013).

Localizado na região portuária do Rio de Janeiro, o Píer Oscar Weinschenck, mais conhecido como Píer Mauá, pode ser considerado um estudo de caso importante para aprofundar o entendimento do chamado "terreno vago". Conforme veremos ao longo do texto, o atracadouro permaneceu por mais de seis décadas numa singular condição de vacuidade. Porém, desde os anos 1990, o vazio urbano tem se convertido num território altamente cobiçado por diversos agentes que vislumbraram em sua localização estratégica a potencialidade de implantação de projetos. Em sua maioria, apresentavam a intenção de criar ícones arquitetônicos capazes de simbolizar a renovação do porto carioca, em processos que envolvessem, simultaneamente, os campos do planejamento urbano, mídia e arquitetura. Apesar das acirradas disputas desencadeadas em torno da ocupação do Píer Mauá e da grande quantidade de projetos apresentados para o local, esse objeto tem sido mantido à margem de estudos acadêmicos específicos. O presente texto pretende discutir as dinâmicas territoriais envolvidas na querela, analisando os projetos de arquitetura propostos para o Píer Mauá (projetos dos anos 1990, Guggenheim Rio e Museu do Amanhã) em conexão com os respectivos planos urbanísticos (Rio Sempre Rio, Porto do Rio e Porto Maravilha) e com as imagens dominantes veiculadas pela mídia (Brasil +500 , Novo Milênio e Sustentabilidade). A análise empírica pretende contribuir para o aprofundamento teórico, refletindo sobre os processos contemporâneos de transformação territorial.

\section{Metodologias e materiais}

A pesquisa adotou a metodologia de estudo de caso para analisar o conceito de terrain vague com base em sua aplicação ao Píer Mauá (YIN, 2001). Para tanto, partiremos da execução de levantamentos bibliográficos, seguida de análise baseada em três entradas principais: projetos de arquitetura, diretrizes estabelecidas pelos planos urbanísticos e artigos de imprensa escrita publicados pelo principal periódico de perfil empresarial do Rio de Janeiro: o jornal O Globo (LAPUENTE, 2016). ${ }^{1}$ As fontes de jornal foram selecionadas por revelarem informações documentais relevantes, considerando-se o papel político-social assumido pelos agentes de mídia e

Revista online do Departamento de Arquitetura e Urbanismo da Pontifícia Universidade Católica do Rio de Janeiro - PUC-Rio, Brasil Ano 8 - N응 - ISSN 2446-7340 
sua heterogeneidade intrínseca. O presente estudo levanta a hipótese de que mídia e planejamento urbano podem ser considerados fatores fundamentais para influenciar o design arquitetônico a partir da análise do Píer Mauá. Além disso, a pesquisa propõe questionamentos secundários: como o Píer Mauá foi ocupado? Atualmente, o Píer atende às demandas da cidade? Foi encerrado o debate sobre sua ocupação? Buscaremos refletir sobre essas questões ao longo do texto, analisando as implicações desses fatores sobre o design arquitetônico contemporâneo.

\section{O Píer Mauá e o planejamento urbano no Rio de Janeiro}

O Píer Mauá é uma infraestrutura urbana espacialmente articulada à Praça Mauá, estruturada em 1910 no local do antigo "Largo da Prainha" (Figura 1). A praça foi criada a partir da reforma urbanística promovida pelo então prefeito Francisco Pereira Passos (1836-1913), responsável pela abertura da Avenida Central (ou Avenida Rio Branco), o principal eixo de ligação da região portuária à Cinelândia. Alinhada ao eixo da avenida, foi instalada na praça uma estátua em homenagem ao Barão de Mauá, do artista Rodolfo Bernardelli (18521931). A Praça Mauá assumiu uma posição importante para a consolidação da imagem de cosmopolitismo metropolitano do Rio de Janeiro, capital federal; acentuada, ainda, pela construção do primeiro arranha-céu do país, o edifício A Noite (1927-1930), projetado pelo arquiteto francês Joseph Gire, em parceria com Elisário Bahiana. A instalação do Jornal A Noite e da Rádio Nacional no edifício contribuiu para a conformação da Praça Mauá como um notável ponto de encontros entre artistas e cantores, tornando-a um local de grande interesse cultural na primeira metade do século XX. A Rádio Nacional assumiu papel importante para difundir pelo Brasil o gosto massivo pelo samba e futebol. No final dos anos 1940, o Brasil se preparava para receber a primeira Copa do Mundo sediada no país, ocasião para a qual foi erguido o maior estádio brasileiro de futebol: o Maracanã, planejado para abrigar 155 mil torcedores.

O Píer Mauá teve suas obras iniciadas em 1948, no mesmo ano em que se começou a ser construído o estádio. $\mathrm{O}$ atracadouro foi concebido como um elemento estruturante para a ampliação da capacidade de funcionamento da zona portuária do Rio de Janeiro. Situado num local estratégico da Baía de Guanabara, a nova infraestrutura portuária seria capaz de recepcionar transatlânticos de grande porte em viagem para a América do Sul, como o Queen Mary e o Queen Elizabeth. Entretanto, assim como o Maracanã, ${ }^{2}$ suas obras não foram concluídas a tempo da realização do evento esportivo e, mesmo depois de finalizado, o píer não pôde ser efetivamente utilizado devido a problemas estruturais. Era "uma estrutura condenada: quando um barco aportava ali, o prolongamento de concreto balançava como uma boia de cimento" (BLOCH, 2015).

Nas décadas seguintes, a antiga visibilidade da Praça Mauá entrou em decadência devido ao esvaziamento político-administrativo causado por fatores como a transferência da capital federal para Brasília, em 1960; e também pela implantação de medidas autoritárias tomadas no contexto da ditadura militar, que contribuíram para a desarticulação da Rádio Nacional e para a queda do desenvolvimento turístico da cidade. Por outro lado, a obsolescência técnica da infraestrutura portuária e a construção do Viaduto da Perimetral ${ }^{3}$ (Figura 2), finalizado em 1978, igualmente contribuíram para acentuar o processo de degradação e desvalorização econômica da área, colaborando para o isolamento da Praça Mauá. A via elevada acarretou o bloqueio visual da relação estabelecida entre a cidade e o mar (GIESE, 2018); a obra implicou, ainda, na destruição parcial e total de diversos edifícios de interesse histórico na região, tais como o Mercado Central e o Hotel Pharoux, situados na Praça XV. A própria estátua do Barão de Mauá acabou sendo deslocada, para compor o espaço livre em frente ao edifício A Noite. Com efeito, os investimentos públicos e privados passaram a se dirigir principalmente para a região oeste da cidade, especialmente para a Barra da Tijuca e Jacarepaguá.

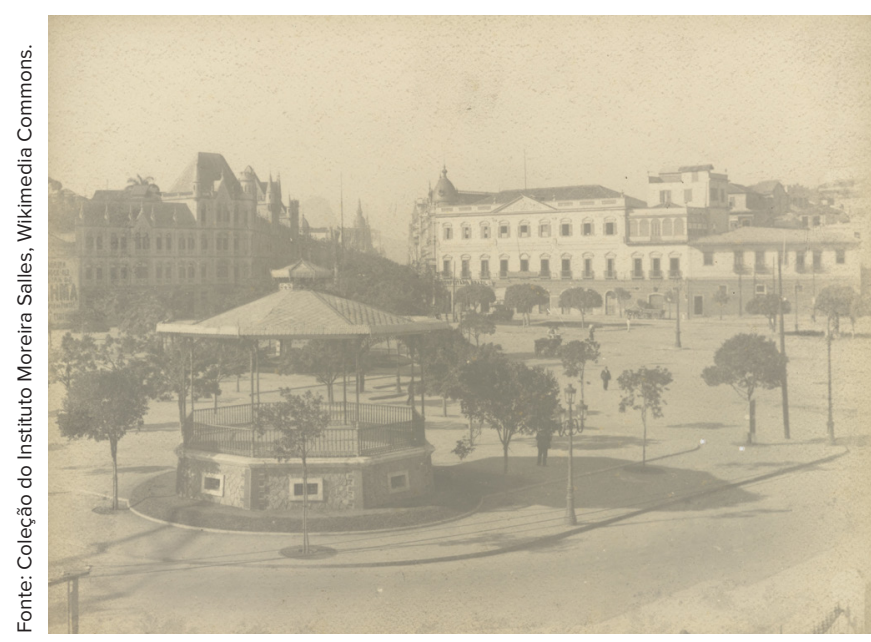

Figura 1. Praça 28 de Setembro, atual Praça Mauá, entre 1910 e 1920. 
De maneira geral, esse contexto foi acompanhado da redução da qualidade de vida na cidade, concomitantemente à expansão desenfreada do processo de metropolização, do crescimento da favelização e do poder paralelo associado ao narcotráfico e às milícias (REIS, 2016). Por essas razões, a preocupação com a "requalificação" da zona portuária adentrou a agenda governamental a partir da década de 1980, buscando reverter o quadro de insegurança empresarial, driblar o desinteresse dos investidores e contornar a dificuldade de estabelecimento do empresariado local. Apesar de contemplar significativos edifícios de interesse histórico-cultural, a zona portuária do Rio de Janeiro vem sendo tratada, no âmbito do planejamento urbano, como uma área passível de modernização (à exceção da linha do cais e dos armazéns). Com efeito, grande parte dos projetos elaborados para a região incorporam as noções de "revitalização" ou "requalificação" urbana. Em 1988, a primeira tentativa de renovação da região ocorreu com a criação do projeto SAGAS (Saúde, Gamboa e Santo Cristo) (GIANNELLA, 2013; MOREIRA, 2004). Entre 1983 e 2001, foram elaborados sete planos com o objetivo de transformar o porto carioca, parcial ou integralmente. Ainda assim, a área permaneceu em precário estado de conservação, apresentando sinais evidentes de má conservação edilícia.

Propriedade privada da Companhia Docas, o Píer Mauá não apresentava acesso aberto ao público desde sua construção. Nos anos 1990, a Companhia passou a alugá-lo para receber eventos privados esporádicos, geralmente mediante pagamento de ingressos: tais como peças de teatro ao ar livre, feiras de arte, celebrações de Ano Novo, shows e mercados culturais (VIANNA, 1996; BRANCO, 2003). As atividades recebidas pelo Píer buscavam inseri-lo competitivamente nos mercados nacional e internacional, baseando-se na promoção de uma imagem forte e positiva da cidade, capaz de atrair investidores. Nesse período, durante a gestão do prefeito Cesar Maia (1993-1997), foi elaborado o Plano Estratégico Rio Sempre Rio (1995), cujas diretrizes buscavam ampliar a visibilidade internacional do município, inserindo-o no circuito internacional de metrópoles globais.

A elaboração do referido plano contou com consultoria catalã de Jordi Borja, Oriol Bohigas, Lluis Milliet e Nuno Portas. Os profissionais foram responsáveis pela concepção do Plano Olímpico de Barcelona, cidade que sediou os Jogos Olímpicos de 1992. A experiência da capital catalã se tornou um caso paradigmático do chamado planejamento estratégico (ARANTES; VAINER; MARICATO, 2013), no qual

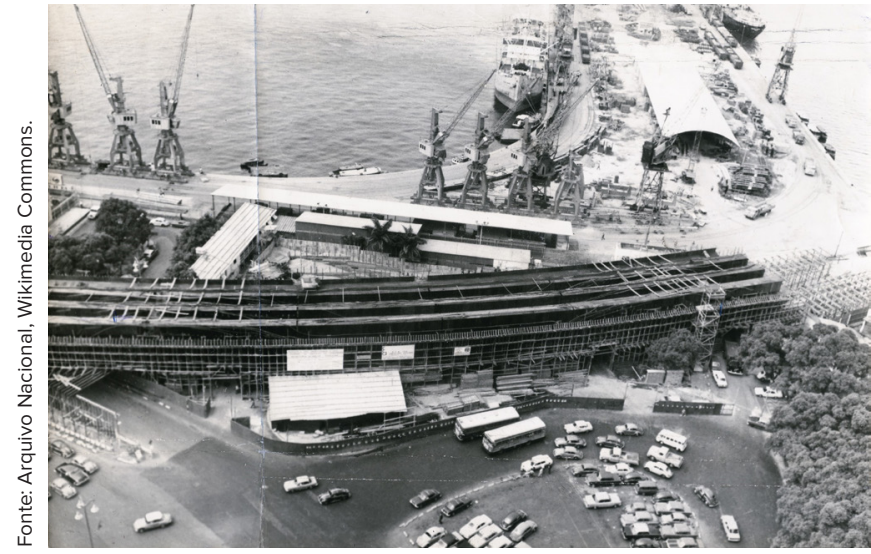

Figura 2. Construção do Elevado da Perimetral, na Praça Mauá. Píer Mauá ao fundo, 1972.

os megaeventos culturais e esportivos exercem papel chave quanto à projeção da imagem internacional do país sede, abrindo possibilidades de atração de investimentos externos em larga escala. $\mathrm{O}$ caso de Barcelona se insere num contexto de estímulo à competividade internacional de cidades pela disputa de investimentos, partindo da definição de pontos estratégicos do território a serem convertidos em novas centralidades. A arquitetura de performance (SPERLING, 2005), desenhada por arquitetos de elevado prestígio internacional, torna-se um elemento importante para simbolizar a recuperação de zonas urbanas degradadas; apesar dos evidentes riscos de que a valorização econômica de determinadas áreas promova a expulsão das populações residentes, promovendo o fenômeno da gentrificação.

A experiência de Barcelona tornou-se um modelo para a ação territorial pretendida para o Rio de Janeiro. Do processo de elaboração do plano para a capital fluminense, nasceu a primeira candidatura da cidade para sediar os Jogos Olímpicos de 2004, rejeitada pelo Comitê Olímpico Internacional. A proposta sugeria a revitalização dos bairros de Santo Cristo, Gamboa e Saúde, priorizando a requalificação da área portuária e a "revitalização do Píer Mauá e dos edifícios adjacentes” (CAMARGO, 2011, p. 105). O Plano Estratégico Porto do Rio (2001) estabeleceu diretrizes urbanísticas semelhantes, incentivando a formação de parcerias público-privadas com o intuito de reverter o esvaziamento da zona portuária, enfatizando sua vocação de lazer, entretenimento e negócios. Em 2004, o Rio de Janeiro empreendeu sua segunda candidatura para sediar os Jogos Olímpicos, novamente rejeitada pelo Comitê Olímpico Internacional.

Apenas a terceira proposta, elaborada em 2006, obteve aprovação. ${ }^{4}$ A Operação Urbana Porto Maravilha, implanta-

Revista online do Departamento de Arquitetura e Urbanismo da Pontifícia Universidade Católica do Rio de Janeiro - PUC-Rio, Brasil Ano 8 - N응 - ISSN 2446-7340 
da por meio da Lei Municipal Complementar № 101/2009 (RIO DE JANEIRO (RJ), 2009) durante o primeiro mandato do prefeito Eduardo Paes, insere-se num contexto em que a cidade se preparava para receber uma série de eventos de grande porte: Conferência das Nações Unidas para o desenvolvimento Sustentável (Rio + 20, 2012), Copa das Confederações (2013), Jornada Mundial da Juventude (2013), Copa do Mundo de Futebol (2014), 450 anos do Rio de Janeiro (2015) e os Jogos Olímpicos (2016). A flexibilização da legislação urbanística contribuiu para a aceleração da realização de obras na cidade, buscando ampliar sua competitividade internacional. Como vemos, o pensamento da revitalização da região portuária do Rio de Janeiro se desenvolveu lentamente ao longo de décadas, sem apresentar alterações substanciais. Em meio a esses processos, o Píer Mauá passou por várias tentativas de ressignificação, protagonizando as discussões sobre a renovação da região portuária.

\section{Arquitetura e eventos celebrativos nos anos 1990}

Na década de 1990, dois eventos celebrativos contribuíram para o pensamento arquitetônico do Píer Mauá: os 500 anos da chegada de Pedro Álvares Cabral ao Brasil (Brasil + 50o) e o Novo Milênio. Ambas as efemérides foram amplamente divulgadas pela mídia, filmes e séries de televisão. A coincidência desses eventos, do ponto de vista simbólico, potencializava a transposição de sentidos em torno de uma recuperação do passado voltada para a construção do futuro. $\mathrm{O}$ Brasil + 500 fazia parte de um processo de nation building, buscando inserir o país no circuito cultural global a partir do reforço das relações luso-brasileiras, importante conexão para a prospecção de negócios a nível global. A festivalização tornou-se um fenômeno recorrente, sendo mobilizado como mote para a realização de intervenções arquitetônicas e urbanísticas a partir de eventos efêmeros ou permanentes, tais como feiras mundiais, jogos ou exposições internacionais (AMBROSIO, 2016). Os 500 anos do Brasil estavam imbricados de um acentuado caráter de efeméride, dada a ausência da tradição celebrativa oficial no dia 22 de abril (SILVA, 2003). Por essa razão, merece destaque o papel assumido pela mídia de massas para a divulgação do evento, em particular a Rede Globo. ${ }^{5}$

Paradoxalmente, o pensamento da arquitetura para o novo milênio imbricou-se de um referencial simbólico high tech, recuperando experiências em voga nos anos 1970, associadas à recuperação de elementos da cultura pop e à mo- bilização de referenciais histórico-simbólicos difundidos no imaginário coletivo e que se voltaram à implantação de um programa multifuncional no Píer. A disseminação do "patriotismo cívico", que busca resgatar a autoestima do brasileiro e do carioca, tornou-se a tônica das intervenções (ARANTES; VAINER; MARICATO, 2013). Em 1994, o arquiteto Paulo Casé sugeriu construir uma torre corporativa próxima à Praça Mauá, contendo hotel cinco-estrelas nos primeiros sete andares e centro de convenções e exposições no subsolo (Figura 3). No Píer Mauá, seriam implantados marina, lojas, restaurantes, estacionamento, centro de cultura e lazer, teatro e salão de concertos. O projeto pretendia apresentar "passado e futuro conjugados, além de uma espécie de nova abertura dos portos através do comércio exterior" (ARRUDA, 1994, p. 24). Seria atracada uma réplica da caravela de Cabral na entrada do Píer com o objetivo de resgatar a imagem do porto como "porta de entrada da cidade" (MOREIRA, 2004, p. 99).

A proposta de Casé para o Píer não foi adiante, apesar de a réplica da caravela de Cabral ter sido efetivamente construída por ocasião das celebrações Brasil + 500, na Base Naval de Aratu (Bahia, 1998). ${ }^{6}$ Por iniciativa do secretário municipal Luiz Paulo Conde e seguindo as diretrizes do plano Rio Sempre Rio, foi aberto um edital público que selecionaria um projeto de arquitetura para o Píer, considerado como "patrimônio cultural do ano 2000" (IDG, 2016). Venceu o concurso o arquiteto Luiz Eduardo Índio da Costa, conhecido pela realização de projetos multidisciplinares a partir de metodolo-

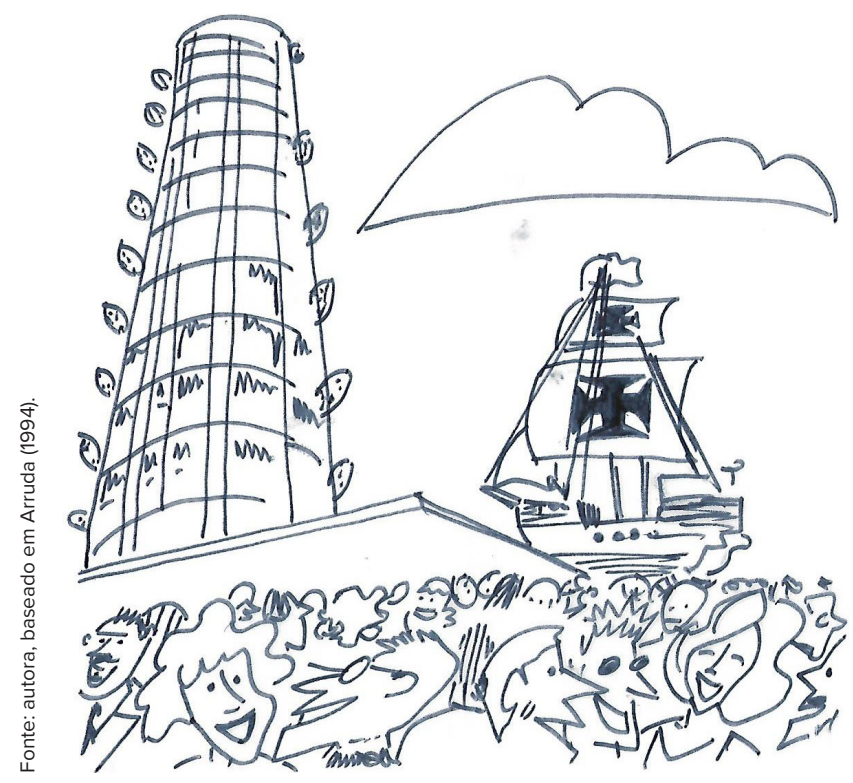

Figura 3. Esboço da proposta de Paulo Casé para o Píer Mauá. 


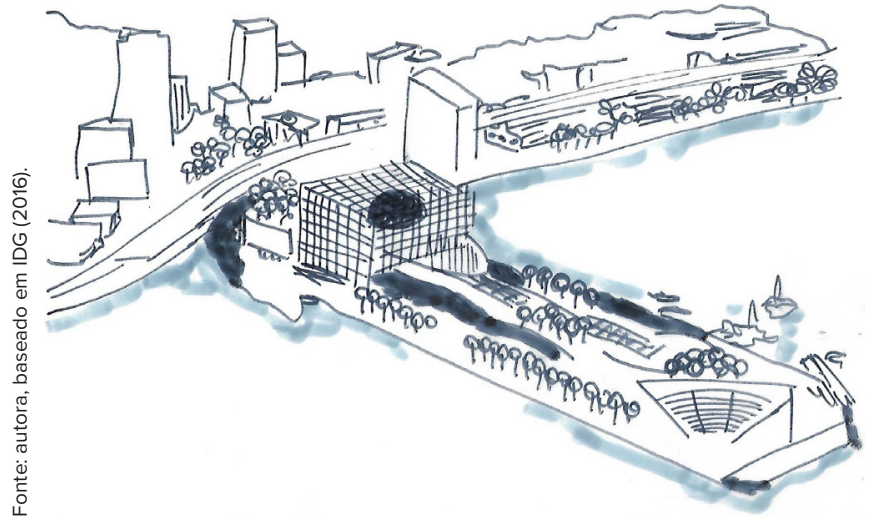

Figura 4. Esboço da proposta de Índio da Costa para o Píer Mauá (1996).

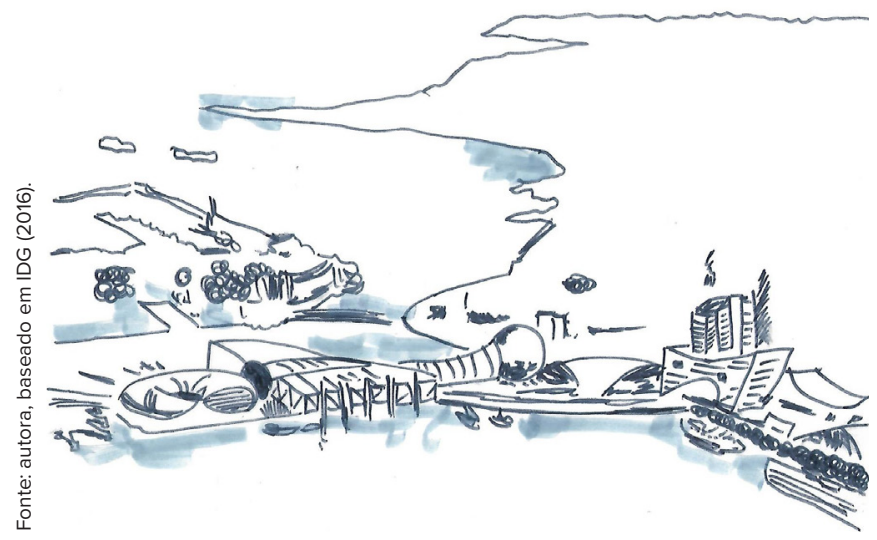

Figura 5. Esboço da proposta de Ronaldo Saraiva para o Píer Mauá (1997).

gias que combinam pesquisa etnográfica, workshops e ações de marketing urbano. O escritório projetou para o Píer Mauá um complexo multifuncional contendo praça, anfiteatro, shopping, centro de entretenimento e de convenções (Figura 4).

Havia uma grande esfera metálica dentro de uma estrutura que remontava formalmente à Biosfera de Montreal, projetada por Richard Buckminster Fuller como Pavilhão dos Estados Unidos para a Exposição Mundial de 1967. Também podem ser recordadas as experiências arquitetônicas dos grupos Archigram, Arc Zoom, Super Studio, UFO, 999, Strum e Site, cujos repertórios arquitetônicos carregavam ironias de ficção científica, voltando-se ao apelo do imaginário high tech da era espacial. Pode-se recordar, inclusive, a presença da geodésica na Cidade das Ciências e da Tecnologia (Parque de La Villette, Paris, 1984-85) e no Rose Center for Earth and Space (Nova Iorque, 200o). Durante o mandato do prefeito Luiz Paulo Conde (1997-2000), o arquiteto Ronaldo Saraiva desenhou para o Píer o projeto "Rio Terceiro Milênio: revitalizando a autoestima do carioca", que incluiria centro de entretenimento, aquário e um "animado museu da história do Brasil” (IDG, 2016) (Figura 5).

Em 1994, foi aberta uma licitação para escolher a empresa privada que administraria o Píer Mauá, vencida por um consórcio liderado pela Companhia Docas, formado por quatro firmas de engenharia (Engepasa, Conter, Lix da Cunha e Iesa). ${ }^{7}$ O projeto apresentado em 1997 criava um edifício corporativo multifuncional com hotel cinco estrelas e shopping center (Figura 6). Entretanto, a prefeitura não autorizou sua execução, encaminhando à Câmara dos Vereadores a diretriz de que o projeto deveria ganhar feições "culturais, de entretenimento e lazer” (CORDEIRO, 2001). Então, o consórcio enviou uma segunda proposta com lojas, restaurantes, cafés, cinema, teatro, centro de convenções e sala de exposições, coroados por uma esfera metálica contendo sala de projeções 360o "num estilo futurista” (ANTUNES e SCHIMIDIT, 1999) (Figura 7).

A larga variedade de propostas arquitetônicas durante os anos 1990 demonstra a falta de consenso sobre a estética e o programa arquitetônico a serem implantados, que oscilaram

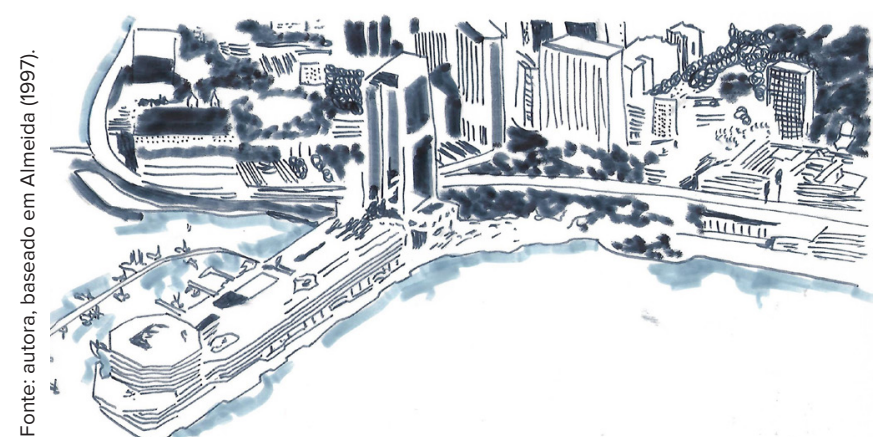

Figura 6. Esboço da proposta da Companhia Docas para o Píer Mauá (1997).

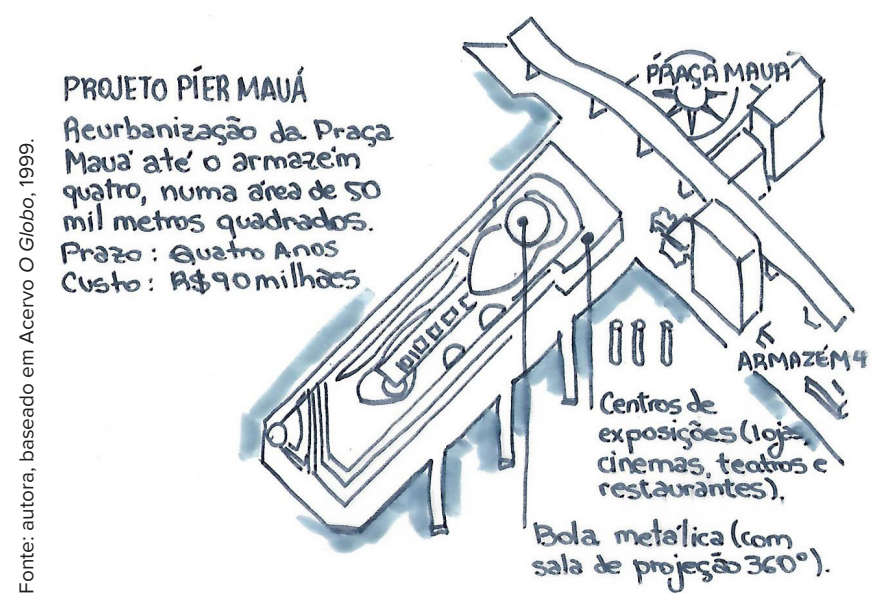

Figura 7. Esboço do projeto da Companhia Docas para o Píer Mauá (1999). 
entre figurações colonialistas e expressionismo high tech. A indefinição estilístico-formal, mesclando elementos de alta tecnologia à expressividade de certa cultura pop brasileira, coexistia com a proposição de programas multifuncionais para a ocupação do Píer Mauá. O espírito de animação festiva incorporado pelos projetos, de alguma maneira, recuperava a máxima "menos é maçante”, enunciada por Robert Venturi em Complexidade e Contradição em Arquitetura ${ }^{8}$ como fundamentação teórica para a união entre o vulgar e o simbólico no campo da arquitetura, gerando formas estéticas caracterizadas pelo ecletismo aleatório.

Parece oportuno retomar os conceitos de "pato" e "galpão decorado" cunhados por Venturi, Scott Brown e Izenour em Aprendendo com Las Vegas ${ }^{9}$ (EVERS, 2015). A caravela ao lado da torre, de Casé, pode ser associada ao conceito de "pato", dado seu excessivo figurativismo. Já os projetos de Costa e Saraiva se aproximam ao "galpão decorado", nos quais a arquitetura serve de suporte para pastiches históricos associados a representações futurísticas. As efemérides dos anos 1990, temas de rápida obsolescência, foram formalmente integradas ao design do edifício, resgatando o caráter pop assumido pela arquitetura - cuja reprodução indiscriminada, segundo Demetri Porphyrios (NESBITT, 2016), contribui para o reforço do pensamento hegemônico, diluindo-se em imagens cada vez mais esvaziadas de sentido.

\section{Rio de Janeiro, cidade global: o Guggenheim Rio}

Nos anos 2000, o desejo de integrar o Rio de Janeiro às dinâmicas globais do mercado da arte definiram novas estratégias para a ocupação do Píer Mauá (REIS, 2016). O consórcio liderado pela Companhia Docas tinha sido praticamente dissolvido, e o Píer continuava um espaço indefinido, incorporando programas arquitetônicos variados. O Guggenheim Rio, uma promessa eleitoral da campanha do então prefeito César Maia (2001-2009), foi progressivamente consolidando-se como o principal projeto cogitado para o atracadouro. Durante as celebrações dos 500 anos do Brasil, foi realizada a Mostra do Redescobrimento (São Paulo, 200o), que partiria em itinerância internacional, sendo exibida pelos museus Guggenheim de Nova Iorque e Bilbao. Logo, porém, esse contato converteu-se numa prospecção para a construção de um Museu Guggenheim no Brasil, diante do contexto de expansão internacional da franquia Guggenheim encabeçado pelo então diretor da Fundação, Thomas Krens (OSTLING, 2007).
Após o atentado de 11 de setembro de 2001, a Fundação Guggenheim passou a despender certa prioridade às negociações com o Rio de Janeiro, considerando o declínio de sua euforia expansionista, a retração do turismo internacional e o desaquecimento do mercado financeiro global. A crise instaurou o fechamento do Guggenheim Soho (Nova Iorque, 1992-2001) em menos de dez anos de funcionamento, e o abandono completo do megaprojeto pretendido para East River, em Manhattan, desenhado pelo arquiteto canadense Frank Gehry, que chegaria a ser dez vezes maior que o edifício em Bilbao. As sedes da franquia em Las Vegas também encerraram suas atividades em 2003. Depois de analisar lugares com potencial para sediar o Guggenheim Rio, Krens cogitou instalar o museu no Forte de Copacabana. Porém, Gehry indicou o Píer Mauá como o melhor lugar para receber a intervenção (EICHENBERG, 2010). Essa localização coincidia com as aspirações pretendidas pelo plano urbanístico Porto do Rio, podendo configurar-se como um ícone da pretendida revitalização da zona portuária carioca.

Em 2001, discutia-se a ocupação do Píer Mauá por um museu contemporâneo (possivelmente o Guggenheim); Museu Mundial do Futebol, aquário público, centro de convenções e sala de concertos (BLOCH, 2001). Porém, com o andamento das negociações, o Píer passou a ser progressivamente ocupado apenas pelo Guggenheim Rio, que seria projetado pelo arquiteto francês Jean Nouvel, cujo trabalho mundialmente conhecido incluía o Instituto do Mundo Árabe (Paris, 1981-87) e a Fundação Cartier (Paris, 1991-94) (CASAMONTI, 2011). Em 2003, Nouvel apresentou estudo preliminar de um edifício que praticamente desapareceria na paisagem, abaixo do nível do mar. O arquiteto voltou-se à criação da fantasia narrativa voltada para a meta-realidade carioca, construída a partir da justaposição de fragmentos associada a um percurso de visitação dirigido e dramático (Figura 8).

O arquiteto pretendia "brincar com a evocação de um antigo mito: Atlântida, a cidade perdida, afogada no oceano. Mas de uma forma distante, pois não estamos na Disney World! A cidade é um 'porto submerso', você mergulha debaixo d'água e um jardim é revelado" (MUSÉE GUGGENHEIM [ca. 2002], tradução própria). A entrada do projeto seria marcada por uma lâmina branca que funcionaria como uma grande tela de projeções e sustentaria o logo Guggenheim. Depois de passar pelo hall, o visitante encontraria uma abertura no teto, coberto pela água do mar, e uma porta de aço, de onde veria o reflexo da água através de um vidro, adentrando área subterrânea destinada às exposições de arte contemporânea

Revista online do Departamento de Arquitetura e Urbanismo da Pontifícia Universidade Católica do Rio de Janeiro - PUC-Rio, Brasil Ano 8 - №의 - ISSN 2446-7340 


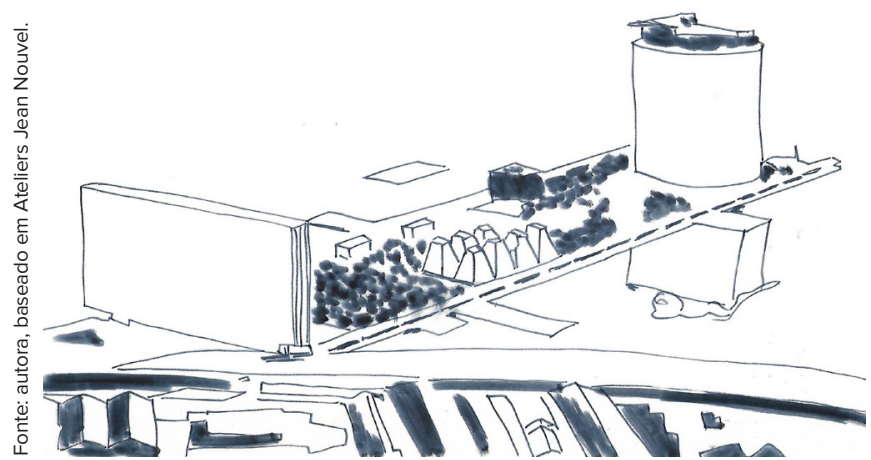

Figura 8. Esboço do Guggenheim Rio, projetado por Jean Nouvel (2002).

brasileira, seguida de pátio contendo uma árvore solitária. Sob o "cais de paralelepípedos", a coleção histórica seria seguida de galerias multimídia, jardim com vegetação tropical e cachoeira com $35 \mathrm{~m}$ de altura. O volume previsto para este local remete inversamente ao relevo carioca ou ao próprio mapa do Brasil. Ao final, o grande cilindro de aço corten conteria exposições temporárias e arte experimental.

O estudo de viabilidade do projeto, realizado pela empresa IDOM, apontou para uma série de questões problemáticas concernentes à construção da floresta tropical subterrânea; risco biológico de proliferação de fungos e pragas; onerosa manutenção das piscinas, cascatas e jardins; altos custos previstos com a demolição quase integral do Píer Mauá; despesas adicionais e contínuas provenientes do bombeamento e limpeza de água; necessidade de frequente manutenção da tela branca e repintura do exterior do cilindro de aço corten; exigências de importação de sofisticadas unidades de ar condicionado, mobília, acessórios e equipamentos de iluminação; dentre outras questões. De acordo com o contrato, a Prefeitura ainda teria que cobrir os gastos de manutenção do museu, cujo plano original previa déficit operacional anual de US\$8 a US\$12 milhões (RIO ESTUDOS, 2002, p. 65).

O projeto foi amplamente criticado por vários setores sociais, sobretudo por causa dos altos custos implicados, ${ }^{10} \mathrm{da}$ inadequação arquitetônica ao clima local e à conservação de acervos (HORTA e TURAZZI, 2003) e da representação simbólica de um Brasil extremamente superficial, reiterando o estereótipo da tropicalidade exótica a ser desbravada pelos visitantes (ARANTES, 2010; LEONÍDIO, 2003). A associação entre países periféricos e cenários místicos desconhecidos, "paraísos perdidos" e naturezas fantásticas já tinha sido evocada pelo arquiteto no Museu Quai Branly (Paris, 1999-2006), tido por alguns autores como "um museu pós-moderno, que infelizmente não é pós-colonial” (THOMAS,
2013, p. 107). Em ambos os casos, os acervos museais legitimariam a construção de um espetáculo capitalista midiático, reforçando o pensamento hegemônico colonial. Porém, a mobilização de uma ação popular embargou o início das obras a partir de uma liminar emitida pela justiça em maio de 2003 devido a irregularidades nos contratos firmados, que foram anulados. O ex-prefeito César Maia e a Fundação Guggenheim foram condenados a devolver US\$2 milhões aos cofres públicos. ${ }^{11}$

\section{Sustentabilidade, espaço público e Museu do Amanhã}

Enquanto isso, a Companhia Docas continuava a alugar o Píer Mauá para eventos privados. Em 2003, a Companhia Hype Babilônia Eventos foi contratada para criar um programa cultural para o Píer Mauá. Nesse período, a Companhia Píer Mauá, (responsável pela Estação Marítima de Passageiros) passou a restaurar armazéns na região portuária para abrigar eventos de entretenimento e exposições. De acordo com o presidente da Companhia, Luiz Cerqueira, pretendia-se abrir completamente o Píer para a fruição pública. $\mathrm{O}$ alinhamento político entre as esferas de governo municipal, estadual e federal se beneficiou do contexto de pujança econômica impulsionado pela exploração da camada Pré Sal. Em maio de 2009, o Rio de Janeiro foi definido como cidade-sede da Copa do Mundo de Futebol (2014) e, em outubro do mesmo ano, dos Jogos Olímpicos (2016).

A Operação Urbana Consorciada Porto Maravilha foi implementada pela Lei Municipal Complementar № 101/2009, segundo a qual o Píer Mauá deveria abrigar "atividades destinadas a lazer, cultura e eventos" (RIO DE JANEIRO (RJ), 2009, p. 9). A Companhia de Desenvolvimento Urbano da Região do Porto do Rio de Janeiro (CDURP) foi instituída para a realização das obras. O projeto tomou como referência as experiências de revitalização de zonas portuárias de São Francisco, Buenos Aires, Londres e Barcelona (DEL RIO, 2001). O "Parque do Píer Mauá” previa sua articulação à Orla Luiz Paulo Conde, contendo a instalação de infraestruturas ao ar livre, tais como pérgolas, quiosques, chafarizes, fontes, praças e um anfiteatro aberto (Figura 9).

Paralelamente, a Fundação Roberto Marinho (FRM), organização privada sem fins lucrativos vinculada ao Grupo Globo, foi encarregada da criação de dois projetos culturais na região portuária do Rio de Janeiro: a Pinacoteca do Rio (futuro Museu de Arte do Rio), instalada no edifício D. João VI, na

Revista online do Departamento de Arquitetura e Urbanismo da 


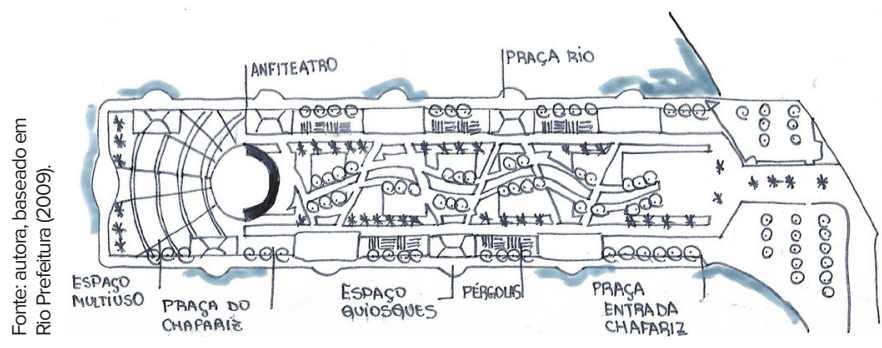

Figura 9. Esboço do Parque do Píer Mauá.

Praça Mauá, e o Museu do Amanhã, que seria inicialmente implantado nos armazéns 5 e 6 . A região portuária do Rio de Janeiro vinha se configurando como um polo cultural, tendo em vista as ações de restauração do Paço Imperial (1985), a abertura do Centro Cultural Banco do Brasil (1989) e da Casa França Brasil (1990), nas proximidades da Praça Mauá. Por sua vez, a FRM vinha se consolidando como importante agente para a construção de museus no Brasil na última década, desenvolvendo aspectos relacionados à museografia interativa e audiovisual, sobretudo a partir da implantação do Museu da Língua Portuguesa (2006) e do Museu do Futebol (2008), ambos em São Paulo.

Entretanto, os planos mudaram depois de uma viagem feita pelo prefeito Eduardo Paes (2009-17) a Londres, Atenas, Barcelona e Valência. O Complexo Olímpico (Atenas, 2001-04), a Torre de Telecomunicações de Montjuïc (Barcelona, 1989-91), a ponte Bach de Roda Felipe II (Barcelona, 1984-87) e a Cidade das Arte e das Ciências (Valência, 19912006) são projetos do arquiteto espanhol Santiago Calatrava localizados nessas cidades. O encantamento com a obra do arquiteto levou o prefeito a sugerir que a FRM transferisse o projeto do Museu do Amanhã para o Píer Mauá, onde seria desenhado por Calatrava. Sua obra tinha se tornado internacionalmente conhecida pela experimentação de estruturas dinâmicas que desenvolvem o tema do dinamismo arquitetônico (JODIDIO, 2016). A arquitetura futurística de inspiração orgânica proposta por Calatrava para o Museu do Amanhã desenvolvia o conceito de sustentabilidade, internacionalmente discutido no Rio de Janeiro nos eventos Eco 92 e Rio + 20. A capital fluminense também integra o grupo C40, que reúne cidades com potencial de atuação frente às mudanças climáticas. O discurso ambiental foi incorporado ao Plano Diretor de Desenvolvimento Sustentável do Município, instituído pela Lei Complementar № 111/2011. Diante desse contexto, tanto a Copa do Mundo de 2014, quanto os Jogos Olímpicos de 2016, incorporaram fortemente a retóri- ca da sustentabilidade ambiental, prometendo ações voltadas para a realização de "jogos verdes".

Para a concepção do projeto, Calatrava realizou uma viagem ao Rio de Janeiro, ocasião em que conheceu alguns lugares da cidade como o Parque Lage, o sítio Burle Marx e o Jardim Botânico. A estrutura de uma bromélia teria influenciado o arquiteto a variar sua linha de pesquisa, voltada para o estudo da forma humana - como no edifício Turning Torso (Malmö, 2005) - para a exploração de estruturas naturais no Museu do Amanhã (Figura 10). A arquitetura passou a incorporar aspectos da discussão internacional sobre a sustentabilidade, sobretudo o tema da eficiência energética, alinhando-se aos padrões de certificação para construções sustentáveis do Green Building Council. Por essa razão, estavam previstas soluções voltadas para garantir a captação de energia solar através de brises-soleils móveis, uso da água da Baía de Guanabara para alimentar o sistema de refrigeração do Museu, reciclagem e reaproveitamento de materiais, além do uso de madeira certificada FSC. Em 2016, o Museu do Amanhã conquistou o selo Ouro na certificação LEED (Leadership in Energy and Environmental Design) e, no ano seguinte, o Prêmio Internacional Mipim Awards na Categoria "Construção verde mais inovadora" (SECRETARIA MUNICIPAL DE CULTURA).

Apesar de não retomar diretamente formas clássicas como léxico arquitetônico, o projeto do Museu do Amanhã evoca o arquétipo do museu-catedral, estruturando-se em torno de uma nave central e duas naves laterais (GAMBARATO, 2006). A filiação clássica e o uso do concreto armado aproximam a arquitetura de Calatrava a temas tradicionalmente desenvolvidos pela arquitetura brasileira (ao contrário do projeto de Nouvel); além de ser, ao menos conceitualmente, mais ade-

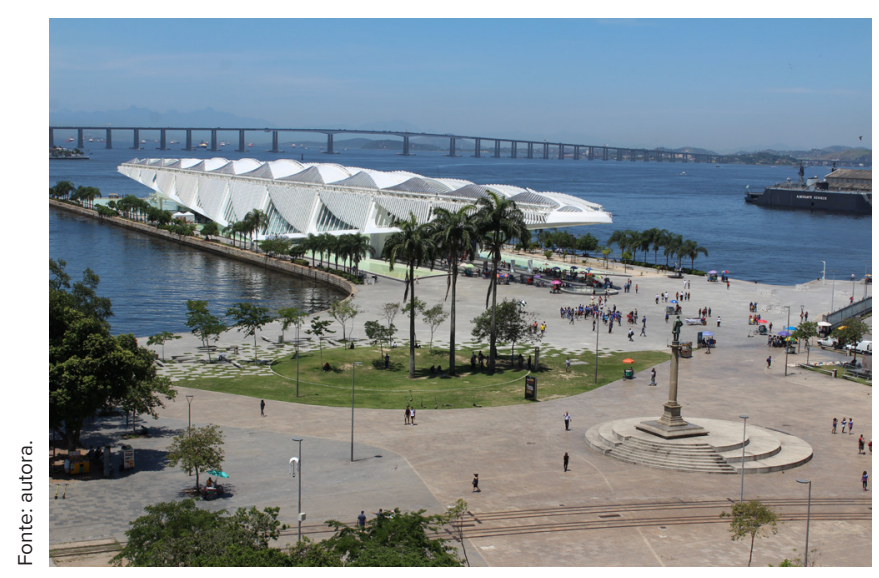

Figura 10. Museu do Amanhã, 2019. 
quada em comparação ao neocolonialismo fantástico do Guggenheim Rio. A implantação urbana do Museu do Amanhã também se mostrava mais convidativa para o usufruto do pedestre do que a proposta anterior, ampliando o acesso à vista para a Baía de Guanabara. Porém, outros aspectos críticos do Guggenheim Rio poderiam também ser aplicados ao Museu do Amanhã, incluindo os altos custos de execução, a ausência de concurso público para a escolha do projeto, a ênfase formalista e a filiação ao chamado star system (ARANTES, 2008), dentre outros aspectos. Como esse projeto conseguiu ocupar o Píer Mauá? Hoje em dia, o Píer atende às demandas da cidade? A construção do Museu do Amanhã encerrou os debates sobre o lugar?

\section{Considerações finais}

O Píer Mauá é um interessante estudo de caso para aprofundar o entendimento do conceito de "terrain vague" proposto por Solá-Morales. A vacância do espaço, sua impossibilidade de funcionar plenamente como atracadouro, a indefinição de usos e a disputa por diversos agentes para sua ocupação são características que poderiam perfeitamente ser utilizadas para descrever o Píer Mauá. A partir dos anos 1990, o Píer não podia ser considerado exatamente uma estrutura abandonada ou sem utilização, tendo em vista a realização de usos efêmeros, de caráter privado e relacionados ao entretenimento cultural. Entretanto, a difusão internacional do planejamento estratégico e o desejo de inserção do Rio de Janeiro na competição global por investimentos privados contribuíram para a consolidação do discurso sobre a subutilização do Píer e o desejo de renovação, possivelmente abrindo o espaço ao acesso público. Nesse contexto, o Píer Mauá tornou-se um privilegiado objeto de disputa por investimentos que, por diferentes razões discutidas ao longo do texto, não puderam ser realizados até que a cidade tivesse sido escolhida para receber a Copa do Mundo de 2014 e os Jogos Olímpicos de 2016.

Os intensos espetáculos esportivos midiáticos acabaram ocasionando a instauração de verdadeiros regimes "de exceção" (VANIER, 2011), dado que a necessidade de se cumprir um calendário inalterável contribui para a acelerada execução de projetos, eventualmente associando-se a violações da legislação, supressão da participação popular e opressão de movimentos sociais (BOTTURA, 2014). No Brasil, o "clima de exceção" foi institucionalizado por meio de dois principais marcos legais: a "Lei Geral da Copa" (BRASIL, 2012) e a "Lei Geral das Olimpíadas" (BRASIL, 2016). Esse contexto permitiu assinalar o desfecho para o Píer Mauá. No entanto, as manifestações de junho de 2013 deram voz ao descontentamento de grande parte da população com determinados aspectos do legado olímpico. O Dossiê do Comitê Popular da Copa e das Olimpíadas do Rio de Janeiro indica que "por trás de toda essa máscara de sustentabilidade [...] percebe-se um legado de violações socioambientais, [...] promovendo a mercantilização da cidade por meio da mercantilização do seu meio ambiente" (COMITÊ, 2015, p. 96).

Por outro lado, a análise dos projetos arquitetônicos desenvolvidos para o Píer Mauá permite perceber que "algo diferente da teoria guia e controla a prática da arquitetura" (HAYS, 2013, p. 255). O design arquitetônico parece ser capaz de assimilar referências variadas, eventualmente externas a seu próprio campo disciplinar, podendo absorver figurativamente elementos presentes em ficções, séries e filmes a partir de abordagens voltadas para a tematização do espaço urbano através da proposição de edifícios multifuncionais. A Tabela 1 sintetiza as conexões entre arquitetura, planejamento urbano e imagens dominantes veiculadas pela mídia. Nos anos 1990, os projetos analisados vincularam-se às efemérides do Brasil + 500 e do Novo Milênio. As sequentes propostas de programas culturais parecem considerar a dimensão multifuncional assumida pelo museu contemporâneo (que passa a incluir restaurantes, cafés, lojas, auditórios para eventos) (RAGONE, 2018). Esse contexto se associa aos processos de aumento significativo do prestígio progressivamente alcançado pelas instituições museológicas, frequentemente tomadas como âncoras de projetos de revitalização urbana e animação cultural, tendo como base o paradigmático caso do Guggenheim de Bilbao (1991-97). A única proposta que se distinguia desse contexto era o Parque do Píer Mauá, aludindo à perspectiva de reincorporação do tecido marítimo para a fruição urbana, democratização da vista para a Baía de Guanabara e garantia do acesso público ao espaço.

A análise das reportagens publicadas pela mídia impressa permitiu não somente o levantamento de informações documentais sobre os projetos, mas também a avaliação de debates e interesses envolvidos sobre sua ocupação, que contribuíram para a consolidação dos impulsos territoriais hegemônicos. O processo de ocupação do Píer Mauá pode ser acompanhado a partir do notável crescimento da quantidade de artigos publicados pelo jornal $O$ Globo nos anos 2010, quando o projeto foi efetivado (Tabela 1). De fato, o próprio

Revista online do Departamento de Arquitetura e Urbanismo da 


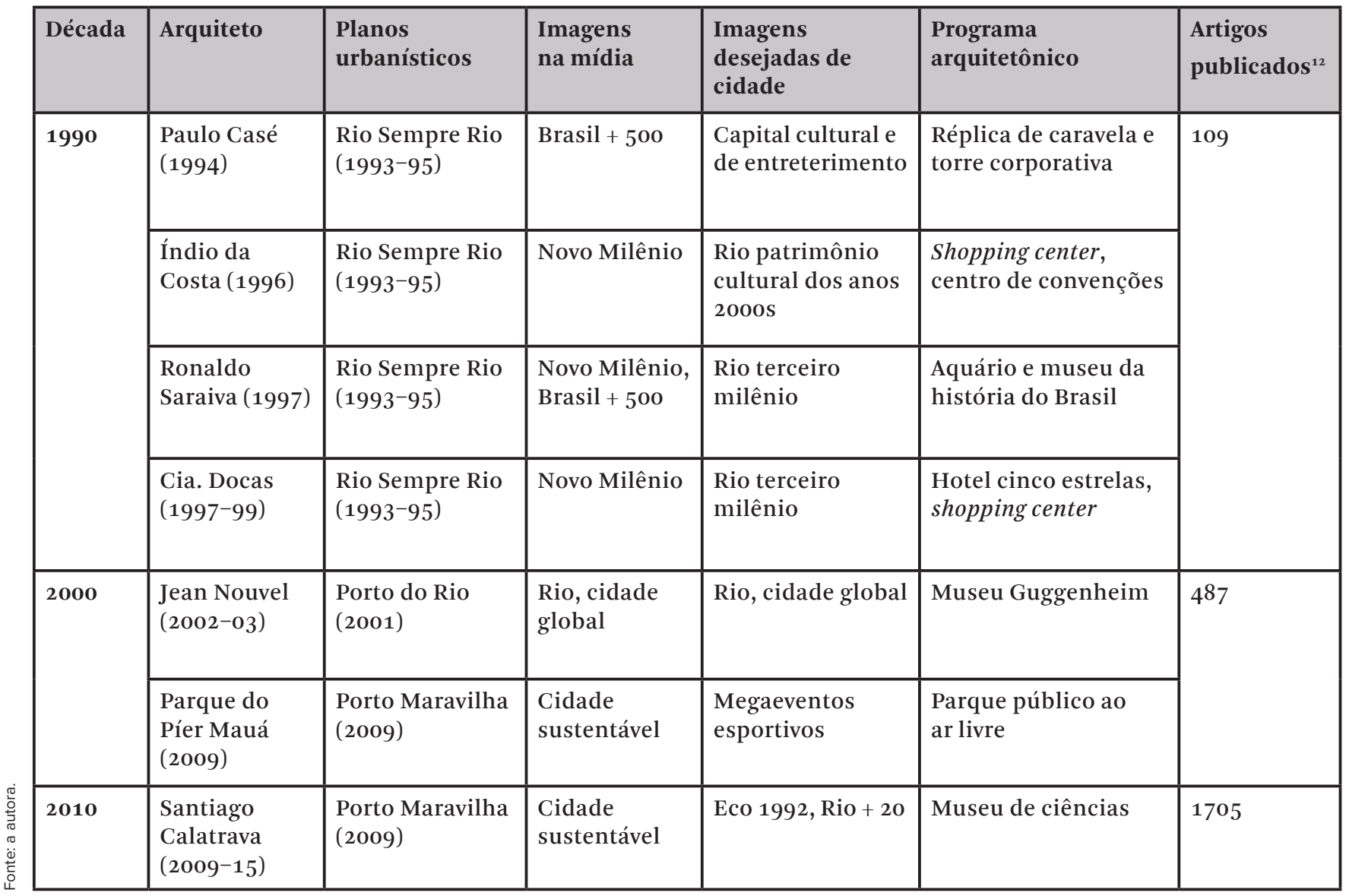

Tabela 1. Projetos para o Píer Mauá, imagens dominantes na mídia e programa arquitetônico.

conglomerado midiático, representado pela FRM, parece ser um agente capaz de moldar e interpretar operacionalmente o contexto político, legislativo e social no Brasil. Além de coordenar as equipes de projeto, a Fundação ainda assume o papel de proponente nas Leis de Incentivo, contribuindo para a captação de recursos (muitas vezes oriundos da própria Rede Globo), de modo a viabilizar a execução de suas propostas.

Devemos, ainda, recordar o chamado "wow factor" (TOKMAN, 2007), conceito de origem empresarial-financeira relacionado à capacidade de um evento causar surpresa ou medo, que é potencializado por possíveis desacordos, disputas ou críticas. Logo, as polêmicas que envolveram os projetos para o Píer Mauá, veiculadas pela mídia, constituem importantes fatores para sua efetivação. Porém, é necessário haver certo nível de consenso social e político para garantir a realização do projeto. Grandes escândalos, eventualmente ligados a denúncias de corrupção, podem efetivamente inviabilizar certos projetos. Nesses casos, a ideia pode ser reproposta para outros locais ou eventualmente para o mes- mo local, assumindo características diferentes. A falência do Guggenheim Rio pode ser considerada uma condição, ou até mesmo uma causa, para a construção do Museu do Amanhã. Além disso, a associação ao tema da Sustentabilidade, amplamente veiculada pela mídia nos anos 2010, também colaborou para a viabilização do museu no Píer.

Ao longo das três décadas analisadas, a grande maioria das propostas realizadas para o Píer Mauá previa a construção de espaços privados de acesso público. A exploração comercial do Píer pela Companhia Docas, focada em atividades de entretenimento, contribuiu para a naturalização da segregação socioespacial como prática recorrente no que diz respeito ao acesso ao Píer - apesar de alguns agentes terem mencionado o desejo de convertê-lo num espaço público. $\mathrm{O}$ Museu do Amanhã conseguiu congregar ambos os desejos, considerando não apenas a possibilidade de a arquitetura museal enriquecer o consumo de experiências culturais (KOOLHAAS, cf. ARANTES, 2010, p. 41), mas também a garantia do acesso público. Externamente, o Píer funciona como um prolongamento da Orla Luiz Paulo Conde, permitindo 
a prática de caminhadas, cooper, pesca, contemplação e lazer. Internamente, o Museu do Amanhã parece se adequar às necessidades da cidade, estimulando o engajamento de visitantes para a realização de ações sustentáveis e contribuindo para a inclusão no espaço museal de públicos não frequentes. ${ }^{13}$ As ações desenvolvidas pelo Museu, em parceria com comunidades locais e escolas públicas, expandem suas funções para além da criação de um ponto turístico. O Museu do Amanhã também funciona como um importante centro de pesquisa, promovendo debates, presenciais e on-line, a respeito de temas contemporâneos importantes. Entretanto, as discussões sobre o futuro do Píer Mauá não parecem estar encerradas. Recentes cortes no orçamento público destinado a instituições culturais no Brasil, aliados aos efeitos da pandemia de COVID-19 a partir de 2020, têm deixado o Museu do Amanhã em um constante estado de incerteza.

\section{Notas de fim:}

1. Os projetos abordados por este estudo foram amplamente divulgados pelo main stream midiático, especialmente pelo Jornal $O$ Globo, do Rio de Janeiro. Seus principais concorrentes nacionais, no que diz respeito à quantidade de tiragem, são os jornais Folha de São Paulo e O Estado de São Paulo. Porém, provavelmente por serem periódicos paulistas, eles apresentaram menor interesse pelos projetos para o Píer Mauá, o que pode ser confrontado com o número reduzido de matérias sobre o tema. Por essa razão, optou-se por não utilizar esses periódicos como fonte de estudo privilegiada para este estudo. Foram analisados, igualmente, jornais cariocas de menor porte, destinados a públicos especializados, tais como Gazeta do Rio e Diário do Rio. No entanto, a maior dificuldade de acesso a bancos de dados dos respectivos jornais tornou-os fontes de pouca relevância para o estudo proposto.

2. O Estádio do Maracanã foi inaugurado às pressas, ainda inacabado. A primeira partida, um amistoso entre as seleções paulista e carioca, ocorreu a apenas uma semana da abertura da Copa do Mundo, com andaimes de madeira ocupando considerável parte das arquibancadas. A concretagem ainda não estava concluída. Apesar dos problemas, o Maracanã recebeu seis partidas da Copa do Mundo; dentre elas, a derrota da seleção brasileira na final para o Uruguai, diante do maior público recebido em toda a história do estádio: 199.854 torcedores (SALGADO, 2020).

3. Desenhado em 1940, o projeto da Avenida Perimetral (Avenida Presidente Juscelino Kubitschek) não previa qualquer elevação em seu traçado original. Apenas a segunda versão do projeto, de 1955, previa a construção da avenida como um viaduto. Em 1978, foi finalizada a construção de seu último trecho, que conectava a Praça Mauá à Ponte Rio-Niterói.

4. Conforme aponta Calabre (2017), o Brasil gastou mais de $\mathrm{R} \$ 180$ milhões em candidaturas para os Jogos Olímpicos desde 1992.

5. Para a veiculação do evento Brasil + 500, a Rede Globo exibiu vinhetas com contagens regressivas na sua programação, realizou shows e instalou relógios nas principais capitais brasileiras, dentre outras ações.

6. O plano era que a Nau Capitânia participasse de uma encenação da "Primeira Missa no Brasil", em Porto Seguro. No entanto, erros no projeto, problemas técnicos e atrasos contribuíram para que a Nau se mostrasse incapaz de navegar e não pudesse participar plenamente da comemoração. Apenas quatro meses depois, a Nau foi ao mar e chegou ao Rio de Janeiro, sendo atracada na Marina da Glória, de onde partiriam passeios turísticos pela Baía de Guanabara.

7. A Companhia Docas era proprietária do Píer Mauá e de grande parte dos imóveis da região.

8. VENTURI, Robert. Complexidade e Contradição em Arquitetura. São Paulo: WMF, 2004.

9. VENTURI, Robert; BROWN, Denise Scott; IZENOUR, Steven. Aprendendo com Las Vegas: o simbolismo esquecido da forma arquitetônica. São Paulo: Cosac Naify, 2003.

10. O custo da obra foi estimado em $\mathrm{R} \$ 500$ milhões, implicando num gasto de $\mathbf{R} \$ 1$ bilhão do município, além do contrato firmado com a Fundação Guggenheim, cujo valor era cerca de três vezes superior ao museu de Bilbao.

11. Embora tenha ocorrido a rescisão do contrato, o dano ao erário já tinha se configurado com o pagamento de US\$2 milhões. Posteriormente, a sentença de primeiro grau confirmou a ilegalidade e, em grau de recurso, o próprio Tribunal de Justiça do Rio de Janeiro manteve a sentença, por meio de acórdão, reconhecendo a ilegalidade e ofensa a princípios administrativos e constitucionais. A questão ainda está sub judice, sendo apreciada pela Justiça. A devolução do dinheiro ainda não ocorreu.

12. Os dados coletados referem-se ao acervo do Jornal O Globo. Nos anos 1950, foram publicadas 69 matérias sobre o Píer Mauá; 39 nos anos 1960; 5 nos anos 1970 e apenas 3 nos anos 1980.

13. Segundo dados apresentados pelo Museu, $48 \%$ do público do Museu do Amanhã não são visitantes habituais de museu, $14 \%$ nunca visitaram um museu antes, $37 \%$ dos visitantes afirmaram ter se engajado em alguma ação depois da visita e $90 \%$ dos visitantes se dizem dispostos a agir para melhorar o amanhã.

\section{Referências Bibliográficas:}

ALMEIDA, Eros Ramos de. Píer Mauá terá hotel, marina e shopping cultural. O Globo, Rio de Janeiro, 02 mar. 1997.

AMBROSIO, Luís Gabriel Denadai. Gestão de projetos urbanos para grandes eventos: os casos de Barcelona, Sevilha e Gênova. Dissertação (Mestrado em Urbanismo) - Programa de Pós-Graduação em Urbanismo, Faculdade de Arquitetura e Urbanismo, Universidade Federal do Rio de Janeiro, Rio de Janeiro, 2016.

ANTUNES, Laura; SCHIMIDIT, Selma. Projetos para remodelar o Rio somam R\$1 bilhão. O Globo, Rio de Janeiro, 14 mar. 1999.

ARANTES, Otília; VAINER, Carlos; MARICATO, Ermínia. A cidade do pensamento único: desmanchando consensos. Petrópolis: Vozes, 2013. 
ARANTES, Pedro Fiori. Arquitetura na era digital-financeira. Desenho, canteiro e renda da forma. Tese (Doutorado em Arquitetura e Urbanismo) - Faculdade de Arquitetura e Urbanismo, Universidade de São Paulo, São Paulo, 2010.

. O grau zero da arquitetura na era financeira. Novos Estudos CEBRAP: Edição 80, São Paulo, v. 27, n. 1, p. 175-195, mar. 2008.

BLOCH, Arnaldo. O Rio renasce no berço do Cais. O Globo, Rio de Janeiro, 25 mar. 2001.

. Píer ganha a solidez de um museu que se quer móvel. O Globo, Rio de Janeiro, 17 dez. 2015.

BOTTURA, Ana Carla de Lira. O paradigma da cidade global e as Olimpíadas do Rio de Janeiro. Oculum Ensaios: Revista de Arquitetura e Urbanismo, Campinas, v. 11, n. 1, p. 119-135, jan.-jun. 2014.

BRANCO, Adriana. Píer Mauá sem naufrágio à vista. O Globo, Rio de Janeiro, 12 out. 2003.

BRASIL. Lei ${ }^{\circ} \mathbf{1 2 . 6 6 3}$, de 5 de junho de 2012. Dispõe sobre as medidas relativas à Copa das Confederações FIFA 2013, à Copa do Mundo FIFA 2014 e à Jornada Mundial da Juventude - 2013, que serão realizadas no Brasil; altera as Leis $\mathrm{n}^{\mathrm{o}} \mathrm{S} 6.815$, de 19 de agosto de 1980 , e 10.671, de 15 de maio de 2003; e estabelece concessão de prêmio e de auxílio especial mensal aos jogadores das seleções campeãs do mundo em 1958, 1962 e 1970. Diário Oficial da União: seção 1, Brasília, DF, p. 3, o6 jun. 2012.

BRASIL. Lei № $\mathbf{1 3 . 2 8 4}$ de 10 de maio de 2016. Dispõe sobre as medidas relativas aos Jogos Olímpicos e Paraolímpicos de 2016 e aos eventos relacionados, que serão realizados no Brasil; e altera a Lei № 12.035, de 1 o de outubro de 2009, que "institui o Ato Olímpico, no âmbito da administração pública federal”, e a Lei № $\mathbf{1 2 . 7 8 0 , ~ d e ~} 9$ de janeiro de 2013, que "dispõe sobre medidas tributárias referentes à realização, no Brasil, dos Jogos Olímpicos de 2016 e dos Jogos Paraolímpicos de 2016". Diário Oficial da União: seção 1, Brasília, DF, p. 1, 11 maio 2016.

CALABRE, Lia Cabral; SIQUEIRA, Maurício. Memória das Olimpíadas no Brasil: diálogos e olhares. Rio de Janeiro: Fundação Casa de Rui Barbosa, 2017.

CAMARGO, Paula de Oliveira. As cidades, a cidade: politica, arquitetura e cultura na cidade do Rio de Janeiro. Dissertação (Mestrado em Bens Culturais) - Fundação Getulio Vargas, Rio de Janeiro, 2011.

CASAMONTI, Marco. Jean Nouvel. São Paulo: Folha de S. Paulo, 2011. Coleção Folha Grandes Arquitetos, v. 8.

COLMENARES, Silvia. De la 'tabula rasa' al 'terrain vague'. El vacío como comienzo. rita_ Revista Indexada de Textos Académicos RITA, Madrid, n. 11, p. 66-73, maio 2019.

COMITÊ Popular da Copa e das Olimpíadas do Rio de Janeiro. Dossiê Megaeventos e Direitos Humanos no Rio de Janeiro: Olimpíada Rio 2016, os jogos da exclusão. 4. versão. [S. 1.]: Comitê Popular da Copa e das Olimpíadas do Rio de Janeiro, 2015. Disponível em: https://br.boell.org/sites/default/files/dossiecomiterio2015 _-_portugues.pdf. Acesso em: 30 nov. 2021.

CORDEIRO, Renato. Companhia Docas refaz contrato do Píer da Praça Mauá. O Globo, Rio de Janeiro, 31 jan. 2001.
DAVIDSON, Cynthia. Introduction. In: Anyplace. Montreal: Canadian Centre for Architecture; Anyone Corporation, 1994.

DEL RIO, Vicente. Voltando às origens. A revitalização de áreas portuárias nos centros urbanos. Arquitextos, São Paulo, ano 2, n. 015.06, Vitruvius, ago. 2001. Disponível em: https://vitruvius.com.br/index .php/revistas/read/arquitextos/o2.015/859. Acesso em: 09, nov. 2021.

EICHENBERG, Fernando. A arquitetura metafísica de Frank Gehry. O Globo, Rio de Janeiro, 11 dez. 2010.

EVERS, Bernd. Teoria da Arquitetura. Do Renascimento até aos nossos dias. Colônia. Taschen, 2015.

FLORES, Enrique. Estrategias de colonización efímera: tácitas informales en la reconfiguración de un terrain-vague. Revista de la Escuela de Arquitectura, Montes de Oca, San José, v. 4, n. 2, p. 53-66, 2015.

GAMBARATO, Roberto. A linguagem do movimento na arquitetura contemporânea. Dissertação (Mestrado em Arquitetura e Urbanismo) - Faculdade de Arquitetura e Urbanismo, Universidade de São Paulo, São Paulo, 2006.

GIANNELLA, Letícia de Carvalho. A produção histórica do espaço portuário da cidade do Rio de Janeiro e o projeto Porto Maravilha: Correspondência entre os grandes ciclos de acumulação capitalista e as morfologias urbanas. Espaço e Economia [on-line], n. 3, ano II, dez. 2013. Disponível em: https://journals.openedition.org /espacoeconomia/445. Acesso em: 30, abr. 2019.

GIESE, Juliana Varejão. Da Belle Époque à Cidade Olímpica: urbanismo, arquitetura e arte pública na Praça Mauá do Rio de Janeiro. Dissertação (Mestrado em Ambiente Construído) - Programa de Pós-graduação em Ambiente Construído, Universidade Federal de Juiz de Fora, Juiz de Fora: 2018.

GÜR, Sengül Öymen. Terrain vague, recycling common ground: esperienze de riciclo architettonico per la rigenerazione urbana. Biennale Sessions. Veneza: 2012, p. 52-57.

HARVEY, David. A produção capitalista do espaço. São Paulo: Annablume, 2005 .

HAYS, Michael. Arquitetura em números. In: SYKES, Krista A. (Org.). o campo ampliado da arquitetura: Antologia teórica 1993-2009. São Paulo: Cosac Naify, 2013, p. 253-262.

HORTA, Maria de Lourdes Parreira; TURAZZI, Maria Inês. Comentários sobre o estudo de viabilidade do Museu Guggenheim-Hermitage-Kunsthistoriches-Rio. Rio de Janeiro: 2003. Disponível em: https:/www.academia.edu/11904246/Coment\%C3\%A1rios_sobre_o _estudo_de_viabilidade_do_Museu_Guggenheim_Rio. Acesso em: 15 , set. 2021.

IDG. O porto do Rio e a construção da alma carioca. Museu do Amanhã. 2016.

JODIDIO, Philip. Calatrava. Architect, Engineer, Artist. Colônia: Taschen, 2016. p. 96.

LAPUENTE, Rafael Saraiva. A imprensa como fonte: apontamentos teórico-metodológicos iniciais acerca da utilização do periódico impresso na pesquisa histórica. Revista de História Bilros. História(s), Sociedade(s) e Cultura(s), [S.1.], v. 4, n. 6, p. 11-29, ago. 2016. 
LEONÍDIO, Otávio. Arquitetura do Desacontecimento: o projeto de Jean Nouvel para o Guggenheim do Rio de Janeiro. Revista Novos Estudos CEBRAP: Edição 66, São Paulo, v. 2, p. 167-178, jul. 2003.

MOREIRA, Clarissa da Costa. A cidade contemporânea entre a tábula rasa e a preservação: cenários para o porto do Rio de Janeiro. São Paulo: UNESP, 2004

MUSÉE GUGGENHEIM. Ateliers Jean Nouvel, [ca. 2002]. Disponível em: http://www.jeannouvel.com/projets/musee-guggenheim/. Acesso em: 23, jun. 2020.

OSTLING, Susan. The global museum and the orbit of the Solomon Museum New York. The International Journal of the Humanities: Annual Review, [S.1.], v. 5, n. 8, p. 87-95, dez. 2007.

PORPHYRIOS, Demetri. A pertinência da arquitetura clássica. In: NESBITT, Kate (Org). Uma nova agenda para a arquitetura: Antologia teórica 1965-1995. Tradução: Vera Pereira. São Paulo: Cosac Naify, 2008, p. 108-114.

QUEM SOMOS. Índio da Costa - A.U.D.T. Disponível em: http:// indiodacosta.com/quem-somos/. Acesso em: 21, out. 2020.

RAGONE, Guilherme Nogueira. As funções dos museus contemporâneos. Dissertação (Mestrado em Ambiente Construído) - Programa de Pós-graduação em Ambiente Construído, Universidade Federal de Juiz de Fora, Juiz de Fora, 2018.

REIS, Patrícia Cerqueira. Rio de Janeiro, uma cidade global? Uma reflexão sobre a construção da Marca Rio. Tese (Doutorado em Ciências da Comunicação) - Escola de Comunicações e Artes, Universidade de São Paulo, São Paulo, 2016.

RIO DE JANEIRO (RJ). Lei Complementar No 101 de 23 de novembro de 2009. Modifica o plano diretor, autoriza o poder executivo a instituir a operação urbana consorciada da região do Porto do Rio e dá outras providências. Rio de Janeiro: Legislação Municipal do Rio de Janeiro, 2009. Disponível em: https://smaonline.rio.rj.gov.br/legis _consulta/32670Lei\%20Compl\%20101_2009.pdf. Acesso em: 10, nov. 2021.

RIO DE JANEIRO (RJ). Lei Complementar № 111 de $1^{o}$ de fevereiro de 2011. Dispõe sobre a Política Urbana e Ambiental do Município, institui o Plano Diretor de Desenvolvimento Urbano Sustentável do Município do Rio de Janeiro e dá outras providências. Rio de Janeiro: Legislação Municipal do Rio de Janeiro, 2011. Disponível em: http:// www.rio.rj.gov.br/dlstatic/10112/6165622/4162211/LC111_2011 _PlanoDiretor.pdf. Acesso em: 08, dez. 2021.

RIO ESTUDOS. Museu Guggenheim. Renovação do Rio: a cidade decide. Prefeitura da Cidade do Rio de Janeiro, 2002.

RIO PREFEITURA. Porto Maravilha. 2009. Apresentação de slides. Originalmente disponível em: CDURP. Porto Maravilha. Disponível em: https://portomaravilha.com.br/. Acesso em: 15, set. 2021.

SALGADO, Diego. Maracanã, 70: Estádio nasceu com obras inacabadas e torcedores pendurados em andaimes às vésperas da Copa do Mundo. UOL Esporte, 2020. Disponível em: https://www.uol.com.br /esporte/reportagens-especiais/maracana-70-anos-estadio-foi -inaugurado-com-obras-e-torcedores-pendurados-em-andaimes/\#cover. Acesso em: 21, out. 2021.

SANT'ANNA, Marcia. A cidade atração: a norma de preservação de áreas centrais no Brasil dos anos 1990. Salvador: EDUFBA, 2017.
SECRETARIA MUNICIPAL DE CULTURA; Instituto de Desenvolvimento e Gestão. Museu do Amanhã. Página inicial. Disponível em: www.museudoamanha.org.br/. Acesso em: 17, nov. 2020.

SILVA, Kelly Cristiane da. A nação cordial: uma análise das ideologias oficiais de "Comemoração dos 500 anos do Brasil". Revista Brasileira de Ciências Sociais, Brasília, v. 18, n. 15, p. 194-214, 2003.

SOLÀ-MORALES, Ignasi de. Territorios. Barcelona: Gustavo Gili, 2002.

SPERLING, David. Museu contemporâneo: e o espaço do evento como não-lugar. In: Atas de Conferência. Seminário Internacional de Museografia e Arquitetura de Museus, São Carlos, 2005.

THOMAS, Dominic. Museums in post-colonial Europe. New York: Routledge, 2013.

TOKMAN, Mert et al. The WOW factor: creating value through win-back offers to reacquire lost customers. Journal of Retailing, [S.1.], v. 83 , n. 1, p. 47-64, 2007.

VANIER, Carlos. Cidade de exceção: reflexões a partir do Rio de Janeiro. In: Anais do XIV Encontro Nacional da ANPUR. Rio de Janeiro, 2011.

VIANNA, Luiz Fernando. Duas festas encerram 96 no Píer Mauá. $O$ Globo, Rio de Janeiro, 1996.

YIN, Robert. Estudo de caso: planejamento e métodos. Porto Alegre: Bookman, 2001. 